\title{
Antecedents of psychological well-being among workers within small and medium enterprises
}

\begin{tabular}{|c|c|}
\hline \multicolumn{2}{|c|}{$\begin{array}{l}\text { Authors: } \\
\text { Eugine T. Maziriri }{ }^{1,4} \\
\text { Tinashe Chuchu }{ }^{2} \\
\text { Nkosivile W. Madinga }^{3}\end{array}$} \\
\hline \multicolumn{2}{|c|}{$\begin{array}{l}\text { Affiliations: } \\
{ }^{1} \text { Department of Marketing, } \\
\text { School of Economic and } \\
\text { Business Sciences, Faculty } \\
\text { of Commerce, Law and } \\
\text { Management, University } \\
\text { of the Witwatersrand, } \\
\text { Johannesburg, South Africa }\end{array}$} \\
\hline $\begin{array}{l}{ }^{2} \text { Department } \\
\text { Management, } \\
\text { Economic and } \\
\text { Sciences, Univ } \\
\text { of Pretoria, Pr } \\
\text { South Africa }\end{array}$ & $\begin{array}{l}\text { f Marketing } \\
\text { Faculty of } \\
\text { Management } \\
\text { ersity } \\
\text { toria, }\end{array}$ \\
\hline \multicolumn{2}{|c|}{$\begin{array}{l}{ }^{3} \text { Department of Marketing, } \\
\text { School of Management } \\
\text { Studies, Faculty of Commerce, } \\
\text { University of Cape Town, } \\
\text { Cape Town, South Africa }\end{array}$} \\
\hline $\begin{array}{l}{ }^{4} \text { Department } \\
\text { Management, } \\
\text { Economic and } \\
\text { Sciences, Univ } \\
\text { Free State, Blo } \\
\text { South Africa }\end{array}$ & $\begin{array}{l}\text { f Business } \\
\text { Faculty of } \\
\text { Management } \\
\text { ersity of the } \\
\text { emfontein, }\end{array}$ \\
\hline \multicolumn{2}{|c|}{$\begin{array}{l}\text { Corresponding author: } \\
\text { Eugine Maziriri, } \\
\text { maziririet@ufs.ac.za }\end{array}$} \\
\hline \multicolumn{2}{|c|}{$\begin{array}{l}\text { Dates: } \\
\text { Received: } 30 \text { Apr. } 2019 \\
\text { Accepted: } 01 \text { July } 2019 \\
\text { Published: } 10 \text { Oct. } 2019\end{array}$} \\
\hline \multicolumn{2}{|c|}{$\begin{array}{l}\text { How to cite this article: } \\
\text { Maziriri, E.T., Chuchu, T., \& } \\
\text { Madinga, N.W., (2019). } \\
\text { Antecedents of psychological } \\
\text { well-being among workers } \\
\text { within small and medium } \\
\text { enterprises. SA Journal of } \\
\text { Industrial Psychology/SA } \\
\text { Tydskrif vir Bedryfsielkunde, } \\
\text { 45(0), a1691. https://doi. } \\
\text { org/10.4102/sajip.v45i0.1691 }\end{array}$} \\
\hline \multirow[b]{2}{*}{ Read online: } & \\
\hline & $\begin{array}{l}\text { Scan this QR } \\
\text { code with your } \\
\text { smart phone or } \\
\text { mobile device } \\
\text { to read online. }\end{array}$ \\
\hline
\end{tabular}

Orientation: In the contemporary business environment, employee mental health is neglected, especially in mental health research and practice in African Small and Medium-sized Enterprises (SMEs). This occurs even though this sector is the largest contributor to developed economies. This study highlights the importance of psychological well-being in SME performance and the individual employee.

Research purpose: To investigate the influence of perceived organisational support, career goal development and empowering leadership on the psychological well-being of SME employees in Gauteng province, South Africa.

Motivation for the study: Despite increasing research on SMEs, few studies have investigated the impact of perceived organisational support, career goal development, and empowering leadership on psychological well-being in a Southern African context.

Research approach/design and method: This study followed a quantitative approach, using the survey methodology where a structured questionnaire was administered to $250 \mathrm{SME}$ employees. To evaluate the psychometric properties of measurement scales, a confirmatory factor analysis was performed. Structural equation modelling was used to test the hypotheses.

Main findings: Perceived organisational support, career goal development and empowering leadership have a positive and significant impact on the psychological well-being of SME workers. A robust, positive and significant relationship exists between empowering leadership and psychological well-being.

Practical/managerial implications: The results indicate that SME managers in South Africa should pay more attention to, or place greater emphasis on, supporting employees in their organisations, recognising and assisting them in achieving their goals, and empowering them to be happy at work. If the psychological well-being of employees is prioritised, SME business performance will ultimately improve.

Contribution/value-add: This study contributes to the current body of Africa's industrial psychology and mental health literature - a field that has received little research attention in developing countries like South Africa.

Keywords: Mental Health; Small and Medium Enterprises; SME; Psychological Well-Being; Mental Health Research.

\section{Introduction}

In most economies, the largest contributors to economic activity are Small and Medium-sized Enterprises (SMEs) (Struwig \& Lillah, 2017). Abor and quartey (2010:218) agree that 'small and medium-sized enterprises (SMEs) are a key part of emerging economies', while Gama and Geraldes (2012) point out that SMEs produce nearly two-thirds of jobs in Europe. The innovative entrepreneurial spirit of the markets is also developed by SMEs (Bishop, 2018). Globally, SMEs are the foundation of economic growth and they find themselves in a competitive environment, as they compete directly with larger entities (Bishop, 2018). In the contemporary African business environment, South African SMEs contribute up to 22\% of the country's Gross Domestic Product (GDP) (Reynolds, Fourie, \& Erasmus, 2019). This supports the view of various scholars (Desiree \& Kengne, 2016; Mafini, Pooe, \& Loury-Okoumba, 2016; Mafundu \& Mafini, 2019; Oyelana \& Adu, 2015) that SMEs are key drivers of economic growth and job creation, as they introduce innovations to tap new markets, boost competition and efficiency across the economy, and reduce poverty and inequality. Small and medium-sized enterprises are essential in improving living standards and national stability (Cant, Wiid, \& Meyer, 2016). 
Given the contribution of SMEs to the economy, it is imperative that the mental health of employees should be prioritised, as they are a critical strategic resource (Martin, Sanderson, Scott, \& Brough, 2009). According to Luo et al. (2008), SME employees usually earn low wages and lack effective long-term occupational health services. Studies have shown that the mental health of SME employees is generally worse than that of the general population and those in big business (Luo, Huang, Ma, \& Wang, 2012; Peng, Long, \& Liang, 2012). Unfortunately, these employees' mental health is also largely neglected in occupational health research and practice (Martin et al., 2009). Zeng et al. (2014) assessed the mental health of SME employees in Guangdong, China, and explored the work environment's related physical and psychosocial factors. According to their results, 35.3\% of employees had a poor sense of Psychological Well-being (PWB) - men, younger employees and migrant workers are more likely to have a poor sense of PWB (Zeng et al., 2014).

It is clear that mental health and employment in SMEs require greater attention. Globalisation and technological advancements have led to an increased demand for employment, subsequently leading to increased job strain (Ratanasiripong et al., 2016). Because mental health is frequently affected by, and has been linked to, work environment or job satisfaction, more research needs to be conducted to study employees' mental health, particularly in SMEs (Ratanasiripong et al., 2016). It is important to note that while many studies focus on SMEs (Gwena \& Chinyamurindi, 2018; Mafundu \& Mafini, 2019; Sitharam \& Hoque, 2016; Struwig \& Lillah, 2017; Wolmarans \& Meintjes, 2015), very few studies address the impact of Perceived Organisational Support (POS), Career Goal Development (CGD) and Empowering Leadership (EL) on the PWB of SME employees.

Previous research in developing nations has examined SME employees in small and medium South African ventures by concentrating on the connection between flourishing at work, work commitment and 'thriving at work' (Van der Walt, 2018). Chinomona and Dhurup (2014) studied the impact of the nature of working life on representative occupation fulfilment, work responsibility and residency in Zimbabwe's SME sector. Literature on SME employees also investigates the impact of authoritative citizenship conduct and representative view of value on hierarchical duty in Zimbabwean SMEs (Chinomona, 2016). Furthermore, studies on SME workforces have also investigated the job satisfaction of SME employees in Thailand (Chaiprasit \& Santidhiraku, 2011). Within a South African context, Joubert and Jonker (2009) examined emotions at work and SME client service worker well-being in Mpumalanga, South Africa.

Despite the availability of SME research, there is limited research on the background that influences PWB. The fundamental motivation behind this investigation is to fill this gap. Very few (if any) researchers have used Structural Equation Modelling (SEM) to test the causal relationships between POS, CGD, EL and PWB. In terms of this study, this robust research model is one of a kind.

The structure of the article is as follows: firstly, a research context is provided and thereafter the theoretical grounding and empirical literature is presented, followed by a conceptual model and a hypothesis development. The research design and methodology are then presented followed by a presentation of the results and the discussions. The final sections of the article discuss the implications, limitations and future research directions.

\section{Rationale and importance of selecting workers in small and medium-sized enterprises}

Cocker, Martin, Scott, Venn and Sanderson (2013) note that there is scant SME-specific research focused on the mental health of SME employees. As a result, available resources are often informed by research carried out in large organisations and developed without evidence that mental health factors in large organisations mirror those of SMEs (Cocker et al., 2013). Martin et al. (2009) point out that SMEs provide an outstanding environment for emotional infection research, as staff are often closer to the feelings of their executives. Some PWB studies were among entrepreneurial ventures (Parasuraman, Purohit, Godshalk, \& Beutell, 1996; Uy, Foo, \& Song, 2013), but a search of more than 700 studies using Ryff's (1989) PWB scale found no reference to small business studies (Ryff's Scale Information Document, 2016). It can be observed from the aforementioned interpretations that SME employees are academically relevant, especially in terms of mental health research. The following section focuses on the study's theoretical framework.

\section{Theoretical grounding}

This study explores the principles of the Social Exchange Theory (SET), the lifespan motivation theory and the empowerment theory, as it relates to the constructs and the relationships proposed between the constructs. These theories are discussed in the following sections.

\section{Social Exchange Theory}

Social Exchange Theory is based on the relational process and the principle of voluntary value exchange between individuals (employer-to-employee) and organisations (businessto-business [B2B]). According to the SET, 'relationship building is based on a subjective cost-benefit analysis and options assessment' (Liu, Min, Zhai, \& Smyth, 2016, p. 54; RobertsLombard et al., 2017, p. 2). This means that the partners in a relationship will assess the future of a relationship on the value still to be accrued from a partner (e.g. financial rewards, a partner's trustworthiness and the level of future relationship satisfaction) (Sierra \& Quitty, 2005:393). In addition, Ward and Berno (2011) opine that:

[S]ocial exchange is not always based on financial rewards, although the continuation of the relationship will be based on views on the comparative costs and benefits of the relationship, experience of satisfaction and its implications for future relationship satisfaction. (p. 1557) 
In this regard, the SET principle of reciprocity explains the positive effects of POS, which is one of PWB's precedents. If employees feel supported, they are likely to return the appreciation through good performance, which, in turn, raises expectations for reward (Kurtessis et al., 2017). The principle of reciprocity is also applied when it is evident that an organisation lacks support or displays abusive behaviour. Poor employee behaviour is likely to result from unfavourable treatment (Cohen-Charash \& Mueller, 2007).

This study postulates that the SET is associated with POS, CGD, EL and PWB. The SET confirms that when an organisation offers tangible and intangible resources, employees will respond in kind (Blau, 1964; Saks, 2006). Perceived organisational support has conventionally been considered as a social exchange process, as it forms the basis of exchange relationships (Blau, 1964; Eisenberger, Huntington, Hutchison, \& Sowa, 1986; Shantz, Alfes, \& Latham, 2016). Scholars have posited that POS acts as a beneficial resource for employees (Ensher, Thomas, \& Murphy, 2001), and some consider career development as a part of the SET (Shantz et al., 2016). According to Su and Swanson (2019), the SET allows for greater levels of organisational trust and identification, which can subsequently enhance employee well-being. Perceived organisational support is a central construct in the SET, and the present study aligns with the limited research available that considers conceptualised POS as an essential resource that can alleviate the negative consequences of work-related attitudes and states (Hochwarter, Witt, Treadway, \& Ferris, 2006; Panaccio \& Vandenberghe, 2009; Witt \& Carlson, 2006).

\section{Motivational Theory of Lifespan Development}

According to Kay and Heckhausen (2015), the Motivational Theory of Lifespan Development (MTD) explains the processes through which humans optimally pursue their development goals. In addition, MTD suggests that people select targets based on opportunities and constraints to promote development across multiple domains, and preserve various objectives (Heckhausen, 1997; Heckhausen \& Schulz, 1993; Heckhausen, Schulz, \& Wrosch, 1998; Schulz \& Heckhausen, 1996). Development is most successful when people pursue suitable goals, engage in goal-oriented efforts to pursue their goals and disengage when goals have been achieved or are no longer achievable (Kay \& Heckhausen, 2015). The MTD has consequences for lifelong achievement of goals, health and well-being (Kay \& Heckhausen, 2015). Shane and Heckhausen (2019), however, claim that the MTD can be applied to a work environment also. The MTD questions aspects of the working life of an individual, including how work and career goals function as development goals that structure and direct the development of individuals; how control capacities and trajectories differ across careers and career stages; and how individuals organise their control efforts to capitalise on career development. As this study investigates the impact of CGD on PWB, the MTD will serve as the theoretical lens.

\section{Empowerment theory}

Budeli (2012) states that one of the best ways to support people's interests is by applying the empowerment theory. Robbins, Chatterjee and Canda (1998) posit that empowerment aims to provide conceptualisations of social stratification and oppression to identify personal and political barriers and dynamics that maintain oppression. In addition, empowerment provides value frameworks to promote human empowerment and liberation and identifies practical strategies to overcome oppression and achieve social justice. The empowerment theory recognises conditions of inequality and injustice (Budeli, 2012) and aims to help marginalised people. Small and medium-sized enterprise employees have the power to ensure effectiveness and social justice in their lives and work environment. Applying the empowerment theory can increase employees' PWB and stimulate SME performance. If SME leaders or managers empower their employees, their employees will feel more active in their organisations and this will help improve the quality of the organisation's output.

\section{Empirical literature}

This section focuses on reviewing literature on the research variables under investigation, namely, POS, CGD, EL and PWB.

\section{Perceived organisational support}

Perceived organisational support refers to the perception of employees regarding the organisation's appreciation of their efforts and care about their well-being (Eisenberger et al., 1986), which may play a crucial role in employee readiness (Gigliotti, Vardaman, Marshall, \& Gonzalez, 2019), especially during organisational change (Gigliotti et al., 2019; Vardaman, Amis, Dyson, Wright, \& Randolph, 2012) . Tremblay, Gaudet and Vandenberghe (2019) consider POS as a collective, commonly accepted view that the organisation supports its members. For employees, POS is expressed through payment, job enrichment, recognition and other benefits. Concern about the well-being of employees is also reflected in the offer of organisational policies and human resources practices that facilitate meeting and balancing job and external demands (Worley, Fuqua, \& Hellman, 2009). Perceived organisational support meets the socio-emotional needs of the employee, contributing to organisational identification, emotional commitment (Kurtessis et al., 2017) and positive impact (Caesens, Stinglhamber, \& Ohana, 2016). Prior literature on POS (Gigliotti et al., 2019; Tremblay et al., 2019) concurs that it epitomises organisations that are concerned for their employees. Other scholars (Arogundade, Arogundade, \& Adebajo, 2015) posit that the personification of organisations is the result of POS. The aforementioned studies did not, however, empirically examine the impact of POS on the PWB of employees.

\section{Career goal development}

Career goal development refers to the objectives that people pursue at work. These goals include promoting, increasing pay and developing skills (Rahim \& Siti-Rohaida, 2015; 
Zikic \& Klehe, 2006). Koekemoer (2014), however, argues that a successful career development by the employee implies that certain organisational objectives have been achieved. Career development takes the form of a lifelong career in one organisation, or a steady climb up the corporate ladder for the individual (Koekemoer, 2014). Career goal development can therefore be defined as individuals' objective or subjective perception of achievements during their work experiences, suggesting an objective and subjective dimension (Koekemoer, 2014). Some researchers postulate that traditional career development models are only marginally effective in the modern global economic context (Dean, Shogren, Wehmeyer, Almire, \& Mellenbruch, 2019). Hu, Hood and Creed (2018) investigated career feedback and stress, while Dickmann and Cerdin (2018) explored career development and transfer of career capital, such as skills and connections. These studies did not, however, assess the relationship between CGD and mental health.

\section{Empowering leadership}

Empowering leadership is defined as behaviours that share power with team members, and, in turn, raise the intrinsic motivation levels of all members (Gyu-Park, SikKim, Yoon, \& Joo, 2017). Empowering leaders show four types of behaviours, namely, emphasising the importance of work, providing decision-making participation, fostering confidence that performance will be excellent and removing any bureaucratic constraints (Ahearne, Mathieu, \& Rapp, 2005). These leadership empowerment behaviours are based on Conger and Kanungo's (1988) broad conceptualisation of empowerment. They indicate that empowerment is a process of motivation, rather than a simple delegation of power to employees. A team leader needs to help team members understand the importance of their roles, involve them in the decision-making process, believe in their ability to achieve high performance and simplify administrative rules and procedures in order to be empowered and motivated (Ahearne et al., 2005).

Previous empirical studies have shown substantial evidence of the positive relationship between EL and different team and organisational outcomes, including task performance (Vecchio, Justin, \& Pearce, 2010), job satisfaction (Konczak, Stelly, \& Trusty, 2000; Vecchio et al., 2010), engagement (Konczak et al., 2000) and organisational citizenship behaviour (Yun et al., 2007). Gyu-Park et al. (2017) explain that only a few studies have looked at the influence of EL on employee psychology. It is, therefore, important to understand how leaders influence the mindset and organisational behaviour of employees. Kearney, Shemla, Van Knippenberg and Scholz (2019) posited that EL leads to goal clarity in organisations but failed to address employee mental well-being, while Han, Harold and Cheong (2019) examined empowerment leadership and trust in organisations. The above-mentioned research however did not examine the influence of EL on an employee's PWB.

\section{Psychological well-being}

Psychological well-being refers to positive mental health (Edwards, 2005; Ismail \& Desmukh, 2012). Farrington (2017:47) describes PWB as the 'perception of engaging with life's existential challenges', whereas Winefield, Gill, Taylor and Pilkington (2012:2) describe it as 'a combination of positive affective states such as happiness and functioning with optimal efficacy in individual and social life'. Optimum PWB levels are likely to depend on the external circumstances of an individual, as well as the resources and challenges they face (Farrington, 2017). Psychological well-being has been investigated in various organisational contexts, including employee well-being (Žižek, Treven, \& Čančer, 2015), commitment (Kanten \& Yesiltas, 2015) and job satisfaction (Jones, Hill, \& Henn, 2015), as well as relationships between family and work (Grzywacz \& Butler, 2005). It has been found that PWB is associated with positive results in terms of work performance of an employee. For instance, Wright and Cropanzano (2000) point out that PWB benefits include an increase in an individuals' cognitive functioning and health, and ultimately the happy functioning of society.

Psychological well-being is generally considered necessary for effective human functioning (Ryan \& Deci, 2001). Previous literature on PWB explored workplace collegiality, such as the relationship between employees and PWB (López, Sanderman, Ranchor, \& Schroevers, 2018). Hernandez et al. (2018) assessed PWB as physical health, reinforcing the notion that PWB is essential in organisations. However, these studies did not investigate the impact of POS, CGD and EL on PWB. Robertson and Cooper (2010) found that individuals with higher levels of PWB behave in ways that may lead to higher levels of workplace engagement, which, in turn, affects business success. In this context, it may be concluded that SME employees who display positive PWB are more likely to contribute to positive outcomes, like successful businesses.

\section{Conceptual research model and hypotheses development}

The relationship between the variables investigated in this study is described in a conceptual model (Maziriri, Mapuranga, \& Madinga, 2018). Maziriri et al. (2018) add that a conceptual model schematic diagram helps the readers to visualise the theoretical relationships between the variables in the model and formulate a quick idea of how the problem can be solved. The conceptual model in this study indicates that the predictor variables are POS, CGD and EL. Psychological well-being is the dependent or outcome variable for this study model. A conceptual model to guide the empirical study as shown in Figure 1 was proposed based on a synthesis of the converging literature related to the research variables.

\section{Proposed hypotheses}

The available literature highlights several validated works, which inform the hypotheses for this study. These hypotheses 


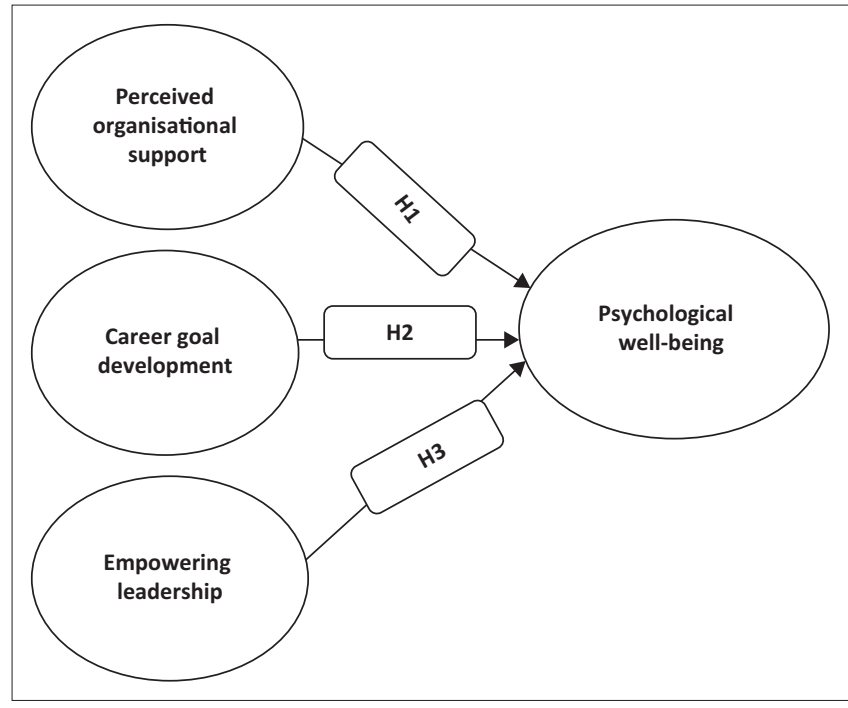

FIGURE 1: Conceptual model.

emphasise specific relationships between variables in a way that allows for empirical testing. The hypotheses are used to validate the theories used in the research and allow for logical analysis of relationships between variables. Based on scientific evidence regarding POS, CGD, EL and PWB, as well as considering the underlying theories, three hypotheses were developed, which are discussed in the following sections.

\section{Perceived organisational support and psychological well-being}

It is imperative to elucidate on the nexus between POS and PWB. Caesens et al. (2016) revealed that PWB is positively linked with overall well-being. In their study that determines the influence of POS and PWB on organisational commitment, Aggarwal-Gupta, Vohra and Bhatnagor (2010) revealed that POS significantly influences PWB and all components of organisational commitment. Roemer and Harris (2018) also pointed out that, in terms of POS, employees with perceived higher levels of organisational support are more likely to experience higher levels of well-being. Perceptions of support seem to foster positive emotions in employees and may be strongly associated with their PWB (Ryff \& Singer, 1998). Therefore, the following hypothesis has been formulated:

H1: POS has a positive and a significant impact on PWB among SME employees.

\section{Career goal development and psychological well-being}

The more focused employees' career goals are, the more likely they are to engage in behaviours that will help them reach their goals, and the greater their motivation to participate in development activities (Rahim \& Siti-Rohaida, 2015). Evidence shows that individuals who actively reflect on career goals and have stronger vision in what they want to attain during their career report a higher level of career success (De Vos \& Soens, 2008). In addition, self-managing individuals are more likely to strive to obtain their desired career goals, which in turn will make them feel more successful in their career (Arthur et al., 2005). In the career literature, goal focus has been shown to be an important determinant of career goal attainment and satisfaction with career progress (Sugalski \& Greenhaus, 1986). Therefore, career goals are expected to influence the level of PWB of individuals (Rahim \& Siti-Rohaida, 2015). However, very few studies have been conducted on the theoretical relationship between CGD and PWB (Rahim \& Siti-Rohaida, 2015). Based on this assumption, a second hypothesis is formulated as follows:

H2: CGD has a positive and significant impact on PWB among SME employees.

\section{Empowering leadership and psychological well-being}

Gyu-Park et al. (2017) explained that empowerment can affect job-related characteristics of PWB, such as skill utilisation and workload. In this vein, Heller and Wilpert (1981) demonstrated that employees' skill utilisation is associated with participatory decision-making, which is a characteristic of empowering leaders (Arnold, Arad, Rhoades, \& Drasgow, 2000). Thus, empowerment can be an effective means to maintain job satisfaction and reduce burnout when an employee's workload is increased (Andrews, Wilmington, \& Kacmar, 2014). Empowering leadership focuses on the relationship between leaders and subordinates, while attending to individual psychological reasons for motivation (Thomas \& Velthouse, 1990). In another study, Fitzsimons and Fuller (2002) showed that having a sense of empowerment is associated with reduced psychological distress. They also reported a positive association between psychological empowerment and self-esteem. Molix and Bettencourt (2010) posited that psychological empowerment partially mediates the relationship between group identity and PWB. Along these lines, deriving from the literature and the empirical proof above, it is hypothesised that:

H3: EL has a positive and significant impact on PWB among SME employees.

\section{Research methodology}

This article pursues a positivist paradigm, as it tries to discover a connection between constructs expressed for this examination, and utilises target estimation instruments for the information gathering and investigation methods. A quantitative research approach was employed, as it elevates result accuracy through statistical analysis. The target population for this investigation includes employees of SMEs situated in the Gauteng province of South Africa during 2019, when the data were gathered. The sampling frame for the examination comprises SME workers in the Gauteng province. A total of 1945 SMEs in Gauteng province were acquired from the Small Enterprise Development Agency (SEDA), a focal point of small enterprise development in South Africa, as the study sample. Respondents were given a questionnaire to complete. The simple random probability sampling strategy (using the Raosoft test calculator) was used to select the respondents. The assessed 
populace of 1945 was used, with a margin error of 5\%, confidence interval of $95 \%$ and response distribution of $50 \%$ - thus resulting in a sample size of 321 SME workers.

\section{Measuring instrument}

For this study, a self-administered questionnaire was used to collect the necessary data. Leedy and Ormrod (2010:197) describe a questionnaire as a research instrument in which a researcher poses a series of questions to willing respondents and summarises their responses with percentages, frequency counts or more sophisticated statistical indexes, upon which inferences are made about a population. Because of the nature of this research, a questionnaire was deemed the most appropriate data collection method. The questionnaire was categorised into five sections, all of which are described in the following.

Section A of the questionnaire comprises demographic questions, such as gender, age, level of education, number of employees (full-time) in the business and age (years) and location of the business. Section B assesses POS and comprises eight items adapted from Eisenberger et al.'s (1986) study, with a Cronbach's alpha of 0.93. In Section C, CGD was measured using four items adapted from Rahim and Siti-Rohaida's (2015) work, which had a composite reliability value of 0.901 . Section $\mathrm{D}$ of the questionnaire comprises questions on EL that were assessed using a 12-item scale adapted from Gyu-Park et al. (2017), with a Cronbach's alpha of 0.97. Section E measures PWB and adapted five items from the scale used by Zeng et al. (2014), which met the reliability criteria with a Cronbach's alpha of 0.61. Responses were recorded using a five-point Likert scale ranging from 1 (strongly disagree) to 5 (strongly agree) for all the variables in this study.

In terms of reliability, all Cronbach's alpha coefficients were above 0.8 , exceeding the expected value of 0.7 (Nunnally \& Bernstein, 1994). The Cronbach's aplha values are as follows: POS (0.795), CGD (0.782), EL (0.818) and PWB 0.742, respectively. A more detailed presentation of the reliability and validity results is given in Table 2.

\section{Data analysis}

The data gathered from SMEs were recorded on an Excel spreadsheet after screening returned questionnaires. The data were analysed using a software for descriptive statistics, Cronbach's alpha values and correlations, and the Statistical Package for Social Sciences (SPSS version 25.0). To test the psychometric properties of the measurement scales, and the hypotheses, the Analysis of Moment Structures (AMOS version 25.0) statistical software was used.

\section{Demographic profile summary}

In the wake of checking for missing values and anomalies, it was found that 250 questionnaires out of the sample of 321 were completed (a 77.8\% response rate). Of these, 71 were unusable because a few items on the questionnaires were not answered. Table 1 presents the classification of information related to gender. The largest proportion of the sample indicated that they were men $(62.4 \% ; n=156)$, followed by those who revealed that they were women $(33.2 \% ; n=83)$. The remaining $4.4 \%(n=11)$ preferred not to mention their gender.

Most of the respondents $(32.4 \% ; n=81)$ were between 50 and 59 years old, 30.0\% $(n=75)$ were between 31 and 39 years old, 18.4\% ( $n=46)$ were between 40 and 49 years old, $12.4 \%(n=31)$ were between 18 and 30 years old, and the remaining $6.8 \%(n=17)$ revealed that they were 60 years and above.

In terms of the level of education, $37.6 \%$ of respondents had a diploma, 30.0\% $(n=75)$ had degrees, $20.0 \%(n=50)$ had no formal education and the remaining $12.4 \%(n=31)$ had only obtained some basic education.

The employment figures for this specific sample profile (Table 1) indicate that most of the SME businesses employ fewer than 50 employees, 44\% $(n=110)$ employ 10 50 employees, 32\% employ 100-200 employees, $21.2 \%(n=$ 53) employ 50-100 employees, with the remaining $2.4 \%$ ( $n=$ 6) employing fewer than 10 employees. These findings coincide with the findings of Moodley (2002:37), who asserts that 'SMEs are important, because, although recruiting less

TABLE 1: Sample demographic characteristics.

\begin{tabular}{|c|c|c|}
\hline Characteristics & Frequency & Percentage \\
\hline \multicolumn{3}{|l|}{ Gender } \\
\hline Male & 156 & 62.4 \\
\hline Female & 83 & 33.2 \\
\hline Prefer not to say & 11 & 4.4 \\
\hline Total & 250 & 100.0 \\
\hline \multicolumn{3}{|l|}{ Age distribution of the respondents } \\
\hline $18-30$ years & 31 & 12.4 \\
\hline $31-39$ years & 75 & 30.0 \\
\hline $40-49$ years & 46 & 18.4 \\
\hline $50-59$ years & 81 & 32.4 \\
\hline 60 years and above & 17 & 6.8 \\
\hline Total & 250 & 100.0 \\
\hline \multicolumn{3}{|l|}{ Level of education } \\
\hline No formal education & 50 & 20.0 \\
\hline Basic education & 31 & 12.4 \\
\hline Diploma & 94 & 37.6 \\
\hline Degree & 75 & 30.0 \\
\hline Total & 250 & 100.0 \\
\hline \multicolumn{3}{|l|}{ Number of employees (full-time) } \\
\hline Less than 10 employees & 6 & 2.4 \\
\hline Between 10 and 50 employees & 110 & 44.0 \\
\hline Between 50 and 100 employees & 53 & 21.2 \\
\hline Between 100 and 200 employees & 81 & 32.4 \\
\hline Total & 250 & 100.0 \\
\hline \multicolumn{3}{|l|}{ The location of the business } \\
\hline CBD & 65 & 26.0 \\
\hline Industrial & 185 & 74.0 \\
\hline Total & 250 & 100.0 \\
\hline
\end{tabular}

$\mathrm{CBD}$, central business district. 
per entity, their potential for job creation is in numbers'. Table 1 provides the profile of the surveyed SMEs in terms of their location. Most of the respondents $(74 \% ; n=185)$ indicated that their business was local (in the industrial areas of the Gauteng province of South Africa). The remaining $26 \%(n=65)$ indicated that they are located in the various Central Business Districts (CBDs) of the Gauteng province.

\section{Research results}

The results section focuses on the results of Confirmatory Factor Analysis (CFA), hypothesis tests performed through SEM and discussions. A CFA is a unique type of factor analysis used to assess whether a construct's measurements are compatible with that construct's nature (Kline, 2011). The SEM method is used to evaluate interactions between variables that are latent (unobservable), such as dependent and independent constructs (Bagozzi \& Yi, 2012; Mafini \& Loury-Okoumba, 2018).

\section{Psychometric properties of measurement scales}

The assessment of the measurement scales' psychometric characteristics was performed through a CFA to determine the construct's reliability, validity and model fit. Table 2 presents the outcomes of the CFA assessment.

The means, Standard Deviations (SD), item to total correlation values, Cronbach's alpha values, composite reliability values, average variance extracted values and standardised factor loadings are reported in Table 2.

As shown in Table 2, mean scores ranging between 3.58 and 4.21 (out of 5.0) were computed for all the constructs examined in the study. These scores depict a collective inclination towards both the 'agree' and 'strongly agree' positions on the Likert scales. As posited by Hair, Babin, Anderson and Tatham (2010), the relationship between the mean and the SD is that a small estimated SD denotes that respondents' responses were consistent and that the response distributions lie close to the mean. Conversely, a large SD indicates that the responses are varying, making the response distribution values fall away from the mean of the distribution (Hair et al., 2010). Moreover, the SD value should be less than 1 , but it is recommended to at least include a value of less than 2 to ensure that there is no issue of outliers (Drost, 2011). Table 2 reveals that the highest SD value was reported at 1.266 and the lowest SD value was 0.881 . This information indicates that the data points are clustered around the mean. The SD values are below 2; hence, it indicates that there was no presence of outliers.

A further analysis of Table 2 reveals that, on POS, three items (POS6, POS7 and POS8) were deleted, as the item to total correlation values were less than 0.5. On EL, four items (EL9, EL10, EL11 and EL12) were deleted, as the POS8 item to total correlation values were less than 0.5. On PWB, two items were deleted, namely PWB1 and PWB2, as the item to total correlation values were less than 0.5 . It is worth mentioning that all these items were deleted because they did not meet convergent validity, they did not measure at least $50 \%$ of what they were supposed to measure. As such, these items did not require further analysis.

According to Nunnally (1978), the reliability of a measure is supported if Cronbach's alpha is 0.7 or higher. The results provided in Table 2 range from the lowest Cronbach's alpha (0.742) to the highest (0.818). Cronbach's alpha scores indicate that each construct exhibits strong internal

\begin{tabular}{|c|c|c|c|c|c|c|c|c|}
\hline Codes & Code items & Mean values & SD values & $\begin{array}{c}\text { Item to total } \\
\text { correlation values }\end{array}$ & $\alpha$ values & CR & AVE & Factor loadings \\
\hline \multirow[t]{5}{*}{ POS } & POS1 & 3.58 & 1.012 & 0.610 & \multirow{5}{*}{0.795} & \multirow{5}{*}{0.830} & \multirow{5}{*}{0.500} & 0.874 \\
\hline & POS2 & 3.67 & 1.085 & 0.539 & & & & 0.838 \\
\hline & POS3 & 4.11 & 1.016 & 0.518 & & & & 0.543 \\
\hline & POS4 & 3.79 & 0.964 & 0.551 & & & & 0.679 \\
\hline & POS5 & 3.90 & 1.042 & 0.502 & & & & 0.514 \\
\hline \multirow[t]{4}{*}{ CGD } & CGD1 & 3.75 & 1.055 & 0.528 & \multirow{4}{*}{0.782} & \multirow{4}{*}{0.740} & \multirow{4}{*}{0.420} & 0.619 \\
\hline & CGD2 & 3.87 & 1.035 & 0.619 & & & & 0.790 \\
\hline & CGD3 & 3.79 & 1.074 & 0.593 & & & & 0.562 \\
\hline & CGD4 & 3.59 & 1.077 & 0.608 & & & & 0.605 \\
\hline \multirow[t]{8}{*}{ EL } & EL1 & 4.21 & 0.927 & 0.530 & \multirow{8}{*}{0.818} & \multirow{8}{*}{0.860} & \multirow{8}{*}{0.430} & 0.603 \\
\hline & EL2 & 3.96 & 1.011 & 0.543 & & & & 0.610 \\
\hline & EL3 & 3.88 & 1.001 & 0.561 & & & & 0.700 \\
\hline & EL4 & 3.85 & 0.978 & 0.598 & & & & 0.736 \\
\hline & EL5 & 3.91 & 1.058 & 0.538 & & & & 0.633 \\
\hline & EL6 & 4.07 & 0.971 & 0.621 & & & & 0.590 \\
\hline & EL7 & 3.78 & 1.177 & 0.591 & & & & 0.728 \\
\hline & EL8 & 3.58 & 1.266 & 0.581 & & & & 0.649 \\
\hline \multirow[t]{3}{*}{ PWB } & PWB3 & 4.12 & 0.881 & 0.596 & \multirow{3}{*}{0.742} & \multirow{3}{*}{0.770} & \multirow{3}{*}{0.540} & 0.539 \\
\hline & PWB4 & 3.86 & 1.047 & 0.500 & & & & 0.720 \\
\hline & PWB5 & 4.08 & 0.884 & 0.598 & & & & 0.893 \\
\hline
\end{tabular}

POS, Perceived organisational support; CGD, career goal development; EL, empowering leadership; PWB, psychological well-being; SD, standard deviation; CR, composite reliability; AVE, average variance extracted. 
reliability (Lee, 2009). Because the Cronbach's alpha values of the constructs exceeded the recommended value of 0.70 , they met the required threshold, demonstrating that the constructs used to measure variables are very reliable for all the variables.

Table 2 shows the loading of each item on their construct. The lowest value for each respective item loading for the research constructs is 0.514; all the individual item loadings exceed the recommended value of 0.5 (Anderson \& Gerbing, 1988). This indicates that all the measurement instruments are acceptable and reliable, because all the individual items converged well and with more than $50 \%$ of each item's variance shared with its respective construct (Fraering \& Minor, 2006).

Composite reliability and AVE for each construct were also computed and assessed to determine if they met the required thresholds for reliability and validity. As per the results shown in Table 2, the lowest CR value (0.740) is well above the recommended value of 0.6 (Hulland, 1999), while the lowest obtained AVE value (0.420) is above the recommended value of 0.4 (Anderson \& Gerbing, 1988). This indicates that convergent validity was achieved, further confirming excellent internal consistency and reliability of the measurement instruments used. As such, all pairs of constructs revealed an adequate level of discriminant validity (see Table 2). By and large, these results provided evidence for acceptable levels of research scale reliability (Chinomona \& Chinomona, 2013:20; Chinomona \& Mofokeng, 2016).

\section{Discriminant validity}

The inter-construct correlation matrix is used to assess the validity of measurement instruments, specifically discriminant validity (Ab Hamid, Sami, \& Sidek, 2017). Correlations among constructs were evaluated to see if they were lower than 1 . The higher the correlation between variables, the lower the validity of those variables (Kafetzopoulos, Gotzamani, \& Gkana, 2015; Kim, Trail, Woo, \& Zhang, 2011). The inter-construct correlation values must be below 0.6 , and in some cases below 0.85 , to indicate discriminant validity. According to Table 3, the highest correlation value was 0.518 and the lowest correlation value was 0.419 . These correlation values are below 0.85 and, therefore, it can be concluded that there is discriminant validity between all the constructs (Morar, Venter, \& Chuchu, 2015).

\section{Measurement model assessment}

Confirmatory factor analysis was performed to examine the reliability, convergent validity and discriminant validity of the multi-item construct measures. This study used overall acceptable CFA fit indices. According to Schreiber et al. (2006), to meet the acceptable level, the chisquare Chi-sqaure (CMIN) or Degree of Freedom (DF) value must be confined to 1 and 3 . The Goodness of Fit Index (GFI), the Comparative Fit Index (CFI), the
TABLE 3: Correlation matrix.

\begin{tabular}{lcccc}
\hline Variables & POS & CGD & EL & PWB \\
\hline POS & 1 & - & - & - \\
CGD & $0.437 \dagger$ & 1 & - & - \\
EL & $0.457 \dagger$ & $0.469 \dagger$ & 1 & - \\
PWB & $0.419 \dagger$ & $0.501 \dagger$ & $0.518 \dagger$ & 1 \\
\hline
\end{tabular}

POS, Perceived organisational support; CGD, career goal development; EL, empowering leadership; PWB, psychological well-being.

$\dagger$, Correlation is significant at the 0.01 level (2-tailed).

Incremental Fit Index (IFI) and the Tucker-Lewis Index (TLI) must all be equal to or greater than 0.90 in order to be acceptable (Bollen, 1990; Hu \& Bentler, 1995). The Root Mean Square Error of Approximation (RMSEA) must be equal to or less than 0.08 in order to be acceptable (Browne \& Cudeck, 1993). The recommended figures show an acceptable data fit for the general model final assessment, namely: $\chi^{2} /(\mathrm{df})=1.911, \mathrm{GFI}=0.901$, TLI $=$ 0.932 , IFI $=0.965, \mathrm{CFI}=0.958$, Normed Fit Index $(\mathrm{NFI})=$ 0.958 and RMSEA $=0.054$.

\section{Structural model assessment and hypothesis testing}

The results of the CFA were satisfactory and therefore SEM was applied. A model fit analysis was performed for the SEM phase prior to testing the hypotheses. The results show that the ratio between the chi-square and the degree of freedom was 1.976. This is below the recommended threshold of 3.0 and confirms the fitness of the model. The recommended thresholds were, respectively, met by CFI, RMSEA, NFI, TLI, IFI, GFI and Adjusted Goodness of Fit Index (AGFI) values, which were 0.968, 0.056, 0.942, 0.936, $0.959,0.952$ and 0.915 (West, Taylor, \& Wu, 2012). The anticipated conceptual model converged well and made it conceivable for the data collected. The hypothesis path modelling test was developed to regulate the strength and weakness of causal relationships. Figure 2 presents the structural model.

\section{Outcome of hypotheses testing}

In this study, hypotheses testing was determined by path coefficient values as well as the $p$-values for the structural model. In the model, relationships of constructs proposed in this study generate the coefficients of paths. These coefficients form the basis of hypothesis examination.

\section{Outcome of testing hypothesis 1}

Hypothesis 1 states that POS has a positive and significant impact on PWB among workers in SMEs as indicated in Table 4. Based on the results of the final model testing, the relationship between POS and PWB shows a $\beta=0.301$ at $p<0.01$. This evidence demonstrates that hypothesis 1 is supported. Hence, it can be noted that POS influences the PWB of workers within SMEs. It is also worth mentioning that these findings reinforce the results obtained in the study of Caesens et al. (2016), who found that POS is positively correlated with well-being. 


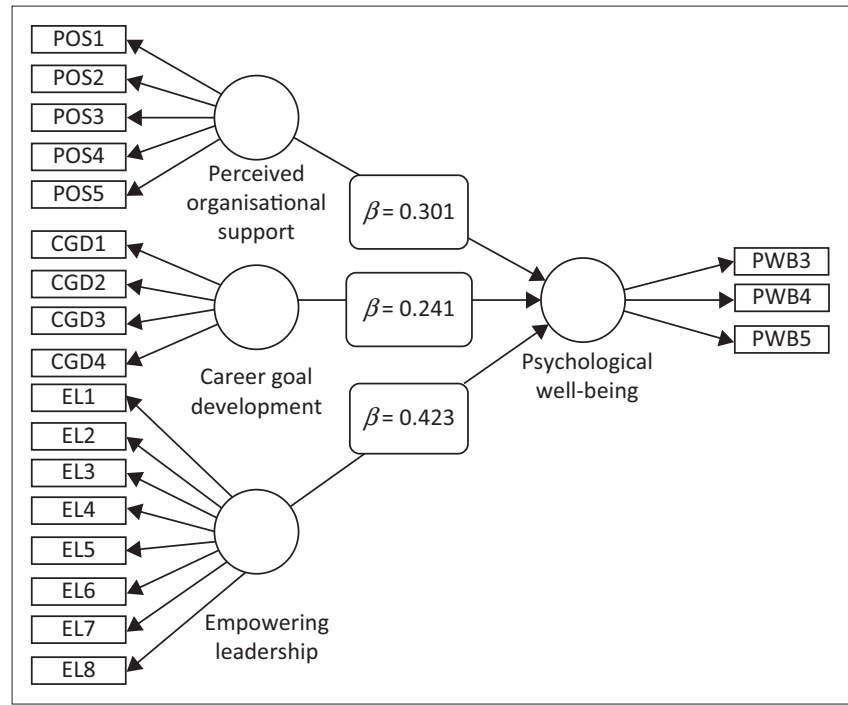

POS, Perceived organisational support; CGD, career goal development; EL, empowering leadership; PWB, psychological well-being.

FIGURE 2: The final structural model of the study.

TABLE 4: Summary of the hypotheses testing

\begin{tabular}{lcccl}
\hline Relationships & Hypothesis & Path coefficient $\boldsymbol{\beta}$ & $\boldsymbol{p}$ & Remarks \\
\hline PWB $\leftarrow$ POS & $\mathrm{H}_{1}$ & 0.301 & $* * *$ & Supported \\
PWB $\leftarrow$ CGD & $\mathrm{H}_{2}$ & 0.241 & $* * *$ & Supported \\
PWB $\leftarrow \mathrm{EL}$ & $\mathrm{H}_{3}$ & 0.423 & $* * *$ & Supported \\
\hline
\end{tabular}

$* * *$, significance level $p<0.01$.

POS, Perceived organisational support; CGD, career goal development; EL, empowering leadership; PWB, psychological well-being.

\section{Outcome of testing hypothesis 2}

Hypothesis 2 asserts that CGD has a positive and significant impact on PWB among workers in SMEs. The final structural model presents the relationship between CGD and PWB results in a coefficient $\beta=0.241$ at $p<0.01$. Thus, hypothesis 2 is supported. These results mean that CGD influences PWB among workers in SMEs. It is also essential to mention that these findings corroborate the results obtained in the works of Rahim and Siti-Rohaida (2015), who elucidated that career goals are expected to influence the level of PWB of individuals.

\section{Outcome of testing hypothesis 3}

Hypothesis 3 states that EL has a positive and significant impact on PWB among workers in SMEs. Based on the results of the final model testing, the relationship between EL and PWB shows a $\beta=0.423$ at $p<0.01$. This evidence demonstrates that hypothesis 3 is supported. These results imply that EL influences PWB. The results obtained in this study also align with the finding of Gyu-Park et al. (2017), who found that employee empowerment can affect PWB.

\section{Ethical considerations}

Permission was granted by the management of the Small Enterprise Development Agency (SEDA). The researchers obtained the permission letter which allowed them to collect data from SMEs registered with SEDA before questionnaires were given out to respondents. Ethical consideration was approved unconditionally and this research study acted in accordance with the ethical standards of academic research, which include, among other things, protecting the identities and interest of respondents and assuring confidentiality of information provided by the respondents. Respondents gave their informed consent to participate in this research and were informed beforehand about the purpose of the investigation to ensure that they were not misled. Despite all the above-mentioned precautions, it was made clear to the respondents that the research was only for academic research purpose and their participation was absolutely voluntary. No one was forced to participate.

\section{Discussion}

The aim of this study was to determine the relationships between POS, CGD, EL and PWB. The results of the analysis suggest that significant relationships can be found between POS, CGD, EL and PWB among SME employees. The relationship between POS and PWB has been extensively studied in industrial psychology literature, which supports the relationship between POS and PWB (Aggarwal-Gupta et al., 2010; Caesens et al., 2016; Roemer \& Harris, 2018). These sources conclude that employees with higher levels of organisational support tend to be in a positive mood in the workplace. The results provide evidence that CGD could predict PWB, as suggested by Robertson (2013). This study's findings reveal a positive and significant relationship between EL and PWB of employees, confirming the conceptual relationship between these variables (Fitzsimons \& Fuller, 2002; Fong \& Snape, 2015; Gyu-Park et al., 2017; Molix \& Bettencourt, 2010).

\section{Managerial implications}

This study presents several implications for academics. An investigation of the research findings indicates that POS and PWB have a strong influence on each other, as indicated by a path coefficient of 0.301 . For academics in the field of mental health, small business management and industrial psychology, this finding would enhance their understanding of the relationship between POS and PWB, making this study an important contribution to the existing literature.

On the practitioners' side, the findings of this study provide solutions from which SME owners and managers can benefit. Given the robust relationship between EL and PWB, as indicated by a path coefficient of 0.423 , managers of SMEs in South Africa should pay attention to or emphasise empowering their employees to have increased PWB and job satisfaction. According to Nel (2013), employees who are empowered have a sense of purpose (their work is vital to them and they are concerned about it), competence (they are confident about their capability to do their work well), self-determination (they freely choose how they do their work and are not micro-managed) and impact (they believe they make an impact at work and their ideas are listened to). 


\section{Recommendations}

The results of this study present opportunities for SMEs in South Africa. Based on the literature analysis and the findings of the empirical research, the following recommendations are made:

- From a management perspective, SME owners and managers must foster a culture that promotes good mental health in SMEs.

- Occupational health nurses, workplace managers and public health officials must raise awareness of the positive benefits of recognising the CGD of employees, they should support employees and empower them to improve their PWB. This will result in improved business performance.

- Managers should be trained in people management skills (with a mental health component). Then they will be able to recognise the signs when an employee becomes less well. This approach should be complemented by training at a peer-to-peer level. Mental Health training will enable staff to provide support to their colleagues.

\section{Limitations and future research suggestions}

The data used in this study were gathered from SME employees and not from those in managerial positions. The results would be more generalisable if data from both groups were compared. The current study was limited to a sample of SMEs in the Gauteng province of South Africa and questionnaires were used to collect the data from respondents. The study's quantitative characteristic may have prompted the disregard of more illuminating and extravagant information, which a qualitative methodology could have created had it been converged in the investigation. Nevertheless, using triangulation would erase the effects of common method bias. Other researchers might opt to use both questionnaires and interviews to strengthen the research.

Future researchers should also focus on other factors that influence the PWB of SME employees. For instance, future researchers should investigate depression, anxiety, happiness and work motivation as predictors of PWB of SME employees. Comparative studies between the findings of this study and those obtained from other firms in different sectors or through meta-analyses should also be considered in the future. This could lead to other thought-provoking insights that were not captured in the present study.

\section{Conclusion}

This study was conducted with the intention of investigating the impact of POS, CGD and EL on the PWB of SME employees in Gauteng province of South Africa. The study validates the assumption that factors like POS, CGD and EL are instrumental in stimulating PWB. Perceived organisational support was positively correlated with $\mathrm{PWB}$ in a significant way, and CGD was found to have a stronger impact on PWB.
A robust relationship was also found on the nexus between EL and PWB.

The results support all the postulated hypotheses, and managerial implications of the findings, limitations of the study and suggested future research were discussed. This study contributes new knowledge to the existing body of mental health, industrial psychology and small business management literature in the African setting - a research context that is often neglected by academics.

\section{Acknowledgements}

The authors would like to say a special thank-you to the Guest Editor, Prof. Willie Tafadzwa Chinyamurindi, and all the anonymous reviewers for their invaluable comments and feedback. The authors are also thankful to the SME employees who responded to this study.

\section{Competing interests}

The authors declare that they have no financial or personal relationships which may have inappropriately influenced them in writing this article.

\section{Authors' contributions}

E.T.M. initiated this research and was the project leader, concept developer, article structure designer, writer and data analyst. T.C. and N.W.M. reviewed the empirical literature section of the article and contributed to the writing of the research introduction and ramifications.

\section{Funding information}

This research received no specific grant from any funding agency in the public, commercial, or not-for-profit sectors.

\section{Data availability statement}

Data sharing is not applicable to this article as no new data were created or analysed in this study.

\section{Disclaimer}

The views and opinions expressed in this article are those of the authors and do not necessarily reflect the official policy or position of any affiliated agency of the authors.

\section{References}

Ab Hamid, M. R., Sami, W., \& Sidek, M.H.M. (2017). Discriminant validity assessment: Use of Fornell \& Larcker criterion versus HTMT criterion. Journal of Physics: Conference Series, 890, 1-5. https://doi.org/10.1088/17426596/890/1/012163

Abor, J., \& Quartey, P. (2010). Issues in SME development in Ghana and South Africa. International Research Journal of Finance and Economics, 39(6), 215-228.

Aggarwal-Gupta, M., Vohra, N., \& Bhatnagar, D. (2010). Perceived organizational support and organizational commitment: The mediational influence of psychological well-being. Journal of Business and Management, 16(2), 105-124.

Ahearne, M., Mathieu, J., \& Rapp, A. (2005). To empower or not to empower your sales force? An empirical examination of the influence of leadership empowerment behavior on customer satisfaction and performance. Journal of Applied Psychology, 90(5), 945-955. https://doi.org/10.1037/0021-9010.90.5.945 
Anderson, J.C., \& Gerbing, D.W. (1988). Structural equation modeling in practice A review and recommended two-step approach. Psychological Bulletin, 103(3) A review and recommended two-step approach. Psycholog

Andrews, M.C., Wilmington, N.C., \& Kacmar, K.M. (2014). Easing employee strain: The interactive effects of empowerment and justice on the role overload-strain relationship. Journal of Behavioral \& Applied Management, 15(2), 43-58.

Arnold, J.A., Arad, S., Rhoades, J.A., \& Drasgow, F. (2000). The empowering leadership questionnaire: The construction and validation of a new scale for measuring leader behaviors. Journal of Organizational Behaviour, 21(3), 249-269. https://doi.org/ 10.1002/(SICI)1099-1379(200005)21:3\%3C249::AID-JOB10\%3E3.0.CO;2-\#

Arogundade, T.O., Arogundade, B.A., \& Adebajo, O. (2015). The influence of perceived organizational support on job stress among selected public and private secto employees in Lagos state, Nigeria. Advances in Research, 3(6), 541-547. https:// doi.org/10.9734/AIR/2015/14048

Arthur, M.B., Khapova, S.N., \& Wilderom, C.P.M. (2005). Career success in a boundaryless career world. Journal of Organizational Behaviour, 26, 177-202.

Bagozzi, R., \& Yi, Y. (2012). Specification, evaluation, and interpretation of structural equation models. Journal of the Academy of Marketing Science, 40(1), 8-34. https://doi.org/10.1007/s11747-011-0278-x

Bishop, W.A. (2018). A project management framework for small- and medium-sized entities: Accounting software implementation. Journal of Economic and Financial Sciences, 11(1), a183. https://doi.org/10.4102/jef.v11i1.183

Blau, P.M. (1964). Exchange and power in social life. New York, NY: Wiley.

Bollen, K.A. (1990). Overall fit in covariance structure models: Two types of sample size effects. Psychological Bulletin, 107(2), 256-259. https://doi.org/10.1037/00332909.107.2.256

Browne, M.W., \& Cudeck, R. (1993). Alternative ways of assessing model fit. In K.A. Bollen \& J.S. Long (Eds.), Testing Structural Equation Models, (pp. 136-159). Newbury Park, CA: Sage.

Budeli, M.C. (2012). Barriers and coping capacities experienced by people living with disability in the Nzhelele area of Limpopo province. Magister Artium thesis. Unpublished Thesis. University of Johannesburg.

Caesens, G., Stinglhamber, F., \& Ohana, M. (2016). Perceived organizational support and well-being: A weekly study. Journal of Managerial Psychology, 31(7) 1214-1230. https://doi.org/10.1108/JMP-01-2016-0002

Cant, M.C., Wiid, J.A., \& Meyer, A. (2016). SMEs: Do they follow a shotgun or rifle approach when it comes to target marketing?. Problems and Perspectives in Management, 14(3), 504-511. https://doi.org/10.21511/ppm.14(3-2).2016.06

Chaiprasit, K., \& Santidhiraku, O. (2011). Happiness at work of employees in small and medium-sized enterprises, Thailand. Procedia-Social and Behavioral Sciences, 25, 189-200. https://doi.org/10.1016/j.sbspro.2011.10.540

Chinomona, E. (2016). Organisational citizenship behaviour and employee perception of equity on organisational commitment, Corporate Ownership \& Control, 14(1) 230-240. https://doi.org/10.22495/cocv14i1c1p6

Chinomona, E., \& Mofokeng, T.M. 2016. Impact of organisational politics on job dissatisfaction and turnover intention: An application of social exchange theory on employees working in Zimbabwean Small and Medium Enterprises (SMEs). on employees working in Zimbabwean Small and Medium Enterprises (SMEs). journal of Applied

Chinomona, R., \& Chinomona, E. (2013). The influence of employees' perceptions of organizational politics on turnover intentions in Zimbabwe's SME sector. South African Journal of Business Management, 44(2), 15-24. https://doi.org/10.4102/ African Journal of
sajbm.v44i2.156

Chinomona, R., \& Dhurup, M. (2014). The influence of the quality of working life on employee job satisfaction, job commitment and tenure intention in the SME sector in Zimbabwe. South African Journal of Economic and Management sector in Zimbabwe. South African Journal of Economic and Man
Sciences, 17(4), 363-378. https://doi.org/10.4102/sajems.v17i4.296

Cocker, F., Martin, A., Scott, J., Venn, A., \& Sanderson, K. (2013). Psychological distress, related work attendance, and productivity loss in small-to-medium enterprise owner/managers. International Journal of Environmental Research and Public Health, 10(10), 5062-5082. https://doi.org/10.3390/ijerph10105062

Cohen-Charash, Y., \& Mueller, J.S. (2007). Does perceived unfairness exacerbate or mitigate interpersonal counterproductive work behaviours related to envy? The Journal of Applied Psychology, 92(3), 666-680. https://doi.org/10.1037/00219010.92.3.666

Conger, J.A., \& Kanungo, R.N. (1988). The empowerment process: Integrating theory and practice. Academy of Management Review, 13(3), 471-482. https://doi.org/ 10.5465/amr.1988.4306983

De Vos, A., \& Soens, N. (2008). Protean attitude and career success: The mediating role of self-management. Journal of Vocational Behaviour, 73, 449-456. https:// doi.org/10.1016/j.jvb.2008.08.007

Dean, E.E., Shogren, K.A., Wehmeyer, M.L., Almire, B., \& Mellenbruch, R. (2019) Career design and development for adults with intellectual disability: A program evaluation. Advances in Neurodevelopmental Disorders, 3(2), 111-118. https:// doi.org/10.1007/s41252-018-0080-6

Desiree, B., \& Kengne, S. (2016). Mixed-gender ownership and financial performance of SMEs in South Africa. International Journal of Gender and Entrepreneurship, 8(2), 117-136. https://doi.org/10.1108/IJGE-10-2014-0040

Dickmann, M., \& Cerdin, J.L. (2018). Exploring the development and transfer of career capital in an international governmental organization. The International Journal of Human Resource Management, 29(15), 2253-2283. https://doi.org/10.1080/095 85192.2016.1239217

Drost, E.A. (2011). Validity and reliability in social science research. Education Research and Perspectives, 38(1), 86-105.
Edwards, S.D. (2005). A psychology of breathing methods. International Journal of Mental Health Promotion, 7(4), 28-34. https://doi.org/10.1080/14623730.2005. 9721958

Eisenberger, R., Huntington, R., Hutchison, S., \& Sowa, D. (1986). Perceived organizational support. Journal of Applied Psychology, 71(3), 500-507. https:// doi.org/10.1037/0021-9010.71.3.500

Ensher, E.A., Thomas, C., \& Murphy, S.E. (2001). Comparison of traditional, stepahead, and peer mentoring on protégés' support, satisfaction, and perceptions of career success: A social exchange perspective. Journal of Business and Psychology, 15(3), 419-438. https://doi.org/10.1023/A:1007870600459

Farrington, S.M. (2017). Psychological well-being and perceived financial performance: An SME perspective. South African Journal of Business Management, 48(4), 47-56. https://doi.org/10.4102/sajbm.v48i4.42

Fitzsimons, S., \& Fuller, R. (2002). Empowerment and its implications for clinical practice in mental health: A review. Journal of Mental Health, 11(5), 481-499. https://doi.org/10.1080/09638230020023

Fong, K.H., \& Snape, E. (2015). Empowering leadership, psychological empowerment and employee outcomes: Testing a multi-level mediating model. British Journal of Management, 20, 126-138. https://doi.org/10.1111/1467-8551.12048

Fraering, M., \& Minor, M.S. (2006). Sense of community: An exploratory study of US consumers of financial services. International Journal of Bank Marketing, 24(5), 284-306. https://doi.org/10.1108/02652320610681738

Gama, A.P.M., \& Geraldes, H.S.A. (2012). Credit risk assessment and the impact of the New Basel Capital Accord on small and medium-sized enterprises: An empirical analysis. Management Research Review, 35(8), 727-749. https://doi.org/ 10.1108/01409171211247712

Gigliotti, R., Vardaman, J., Marshall, D.R., \& Gonzales, K. (2019). The role of perceived organizational support in individual change readiness. Journal of Change Management, 19(2), 86-100.

Grzywacz, J.G., \& Butler, A. (2005). The impact of job characteristics on work-to-family facilitation: Testing a theory and distinguishing a construct. Journal of Occupational Health Psychology, 10(2), 97-109. https://doi.org/10.1037/1076-8998.10.2.97

Gwena, C., \& Chinyamurindi, W.T. (2018). Effects of knowledge management on innovation capabilities amongst small and medium enterprises in South Africa: The case of Buffalo City Metropolitan Municipality. The Southern African Journal of Entrepreneurship and Small Business Management, 10(1), 1-10. https://doi. of Entrepreneurship and Small Bus

Gyu Park, J., Sik Kim, J., Yoon, S.W., \& Joo, B.K. (2017). The effects of empowering leadership on psychological well-being and job engagement: The mediating role of psychological capital. Leadership \& Organization Development Journal, 38(3), of psychological capital. Leadership \& Organization Devel
350-367. https://doi.org/10.1108/LODJ-08-2015-0182

Hair, J.F., Babin, B.J., Anderson, R.E., \& Tatham, R.L. (2010). Multivariate data analysis. A global perspective (7th edn.). London: Prentice-Hall.

Han, S., Harold, C.M., \& Cheong, M. (2019). Examining why employee proactive personalisty influences empowering leadership: The roles of cognition-and affect-based trust. Journal of Occupational and Organizational Psychology, 92(2), 352-383. https://doi.org/10.1111/joop.12252

Heckhausen, J. (1997). Developmental regulation across adulthood: Primary and secondary control of age-related challenges. Developmental Psychology, 33, 176-187. https://doi.org/10.1037//0012-1649.33.1.176.

Heckhausen, J., \& Schulz, R. (1993). Optimisation by selection and compensation: Balancing primary and secondary control in life span development. International Journal of Behavioral Development, 16, 287-303. https://doi.org/10.1177/ 016502549301600210

Heckhausen, J., Schulz, R., \& Wrosch, C. (1998). Developmental regulation in adulthood: Optimization in primary and secondary control - A multiscale questionnaire (OPS-scales). Berlin: Max Planck Institute for Human Development

Heller, F.A., \& Wilpert, B. (1981). Competence and power in managerial decision making. Chichester, NY: John Wiley \& Sons.

Hernandez, R., Bassett, S.M., Boughton, S.W., Schuette, S.A., Shiu, E.W., \& Moskowitz, J.T. (2018). Psychological well-being and physical health: Associations, J.T. (2018). Psychological well-being and physical health: Associations,
mechanisms, and future directions. Emotion Review, 10(1), 18-29. https://doi. mechanisms, and future directions.
org/10.1177/1754073917697824

Hochwarter, W.A., Witt, L.A., Treadway, D.C., \& Ferris, G.R. (2006). The interaction of social skill and organizational support on job performance. Journal of Applied social skill and organizational support on job performance. Journal of App
Psychology, 91(2), 482-489. https://doi.org/10.1037/0021-9010.91.2.482

Hu, L.T., \& Bentler, P.M. (1995). Evaluating model fit. Structural equation modeling: Concepts, issues, and applications. Thousand Oaks, CA: Sage.

Hu, S., Hood, M., \& Creed, P.A. (2018). Career goal importance as a moderator in the relationship between career feedback and career-related stress. Journal of Caree Development, 45(1), 3-18. https://doi.org/10.1177/0894845316667847

Hulland, J. (1999). Use of partial least squares (PLS) in strategic management research: A review of four recent studies. Strategic Management Journal, 20(2), 195-204 https://doi.org/10.1002/(SICI)1097-0266(199902)20:2\%3C195::AID-SMJ13\% 3E3.0.CO;2-7

Ismail, Z., \& Desmukh, S. (2012). Religiosity and psychological well-being. Internationa Journal of Business and Social Science, 3(11), 20-28.

Jones, N., Hill, C., \& Henn, C. (2015). Personality and job satisfaction: Their role in work-related psychological well-being. Journal of Psychology in Africa, 25(4), 297-304. https://doi.org/10.1080/14330237.2015.1078086

Joubert, S., \& Jonker, C.S. (2009). Emotion work and well-being of client service workers within small and medium-sized enterprises. Management Dynamics: Journal of the Southern African Institute for Management Scientists, 18(2), $35-48$. 
Kafetzopoulos, D., Gotzamani, K., \& Gkana, V. (2015). Relationship between quality management, innovation and competitiveness. Evidence from Greek companies. Journal of Manufacturing Technology Management, 26(8), 1177-1200. https:// Journal of Manufacturing Technology
doi.org/10.1108/JMTM-02-2015-0007

Kanten, P., \& Yesiltas, M. (2015). The effects of positive and negative perfectionism on work engagement, psychological well-being and emotional exhaustion. Procedia Economics and Finance, 23(2015): 1367-1375. https://doi.org/10.1016/S22125671(15)00522-5

Kay, J.S., \& Heckhausen, J. (2015). Motivational theory of lifespan development In N.A. Pachana (Ed.), Encyclopedia of Geropsychology, (pp. 1-10). Singapore: Springer.

Kearney, E., Shemla, M., van Knippenberg, D., \& Scholz, F.A. (2019). A paradox perspective on the interactive effects of visionary and empowering leadership. Organizational Behavior and Human Decision Processes. (issue in press). https:// doi.org/10.1016/j.obhdp.2019.01.001.

Kim, Y.K., Trail, G.T., Woo, B., \& Zhang, J. (2011). Sports consumer-team relationship quality: Development and psychometric evaluation of a scale. International Journal of Sports Marketing and Sponsorship, 12(3), 57-74. https://doi.org/ 10.1108/IJSMS-12-03-2011-B006

Kline, R. (2011). Principles and practice of structural equation modelling (3rd edn.) New York, NY: Guilford Press.

Koekemoer, E. (2014). An explorative study on factors influencing the career success of management employees. SA Journal of Industrial Psychology, 40(2), 1-10. https://doi.org/10.4102/sajip.v40i2.1204

Konczak, L.J., Stelly, D.J., \& Trusty, M.L. (2000). Defining and measuring empowering leader behaviors: Development of an upward feedback instrument. Educationa and Psychological Measurement, 60(2), 301-313. https://doi.org/10.1177/ 00131640021970420

Kurtessis, J.N., Eisenberger, R., Ford, M.T., Buffardi, L.C., Stewart, K.A., \& Adis, C.S., (2017). Perceived organizational support: A meta-analytic evaluation of organizational support theory. Journal of Management, 43(6), 1854-1884. https://doi.org/10.1177/0149206315575554

Lee, M.C. (2009). Predicting and explaining the adoption of online trading: An empirical study in Taiwan. Decision Support Systems, 47(2), 133-142. https://doi. org $/ 10.1016 / j . d s s .2009 .02 .003$

Leedy, P.D., \& Ormrod, J.E. (2010). Practical Research: Planning and Design. Ohio: Merrill Prentice Hall.

Liu, Z., Min, Q., Zhai, Q., \& Smyth, R. (2016). Self-disclosure in Chinese micro-blogging: A social exchange theory perspective. Information \& Management, 53, 53-63. https://doi.org/10.1016/j.im.2015.08.006

López, A., Sanderman, R., Ranchor, A.V., \& Schroevers, M.J. (2018). Compassion for others and self-compassion: Levels, correlates, and relationship with psychological well-being. Mindfulness, 9(1), 325-331. https://doi.org/10.1007/s12671-0170777-z

Luo, X.L., Huang, L.L., Ma, J.H., \& Wang, X. (2012). Mental health status and its influencing factors among workers in the small industrial enterprises in Guangzhou City. Occupation Health, 28, 2709-2711.

Luo, Y.Y., He, J.M., Du, W.J., Zeng, W.F., Li, J.L., \& Liu, Y.M. (2008). Survey on occupational hazards of 58 small industrial enterprises in Guangzhou city. Chinese Journal of Industrial Medicine, 21, 186-187.

Mafini, C., \& Loury-Okoumba, W.V. (2018). Extending green supply chain management activities to manufacturing small and medium enterprises in a developing economy. South African Journal of Economic and Management Sciences, 21(1), a1996. https://doi.org/10.4102/sajems.v21i1.1996

Mafini, C., Pooe, D.R.I., \& Loury-Okoumba, V.W. (2016). Interrogating antecedents to SME supplier performance in a developing country. Southern African Business Review, 20, 259-285. https://doi.org/10.25159/1998-8125/6053

Mafundu, R.H., \& Mafini, C. (2019). Internal constraints to business performance in black-owned small to medium enterprises in the construction industry. The Southern African Journal of Entrepreneurship and Small Business Management, 11(1), 10. https://doi.org/10.4102/sajesbm.v11i1.165

Martin, A., Sanderson, K., Scott, J., \& Brough, P. (2009). Promoting mental health in small-medium enterprises: An evaluation of the 'Business in Mind' program. BMC Public Health, 9(1), 239-247. https://doi.org/10.1186/1471-2458-9-239

Maziriri, E.T., Mapuranga, M., \& Madinga, N.W. (2018). Self-service banking and financial literacy as prognosticators of business performance among rural small and medium-sized enterprises in Zimbabwe. The Southern African Journal of Entrepreneurship and Small Business Management, 10(1), 1-10. https://doi. org/10.4102/sajesbm.v10i1.180

Molix, L., \& Bettencourt, B. (2010). Predicting well-being among ethnic minorities: Psychological empowerment and group identity. Journal of Applied Social Psychology, 40(3), 513-533. https://doi.org/10.1111/j.1559-1816.2010.00585.x

Morar, A., Venter, M., \& Chuchu, T. (2015). To vote or not to vote: Marketing factors influencing the voting intention of university students in Johannesburg. Journal of Economics and Behavioral Studies, 7(6), 81-93.

Moodley, S. (2002). Global market access in the Internet era: South Africa's wood furniture industry. Internet Research: Electronic Networking Applications and Policy, 12(1), 31-42.

Nel, T. (2013). Investigating positive leadership, psychological empowerment, work engagement and satisfaction with life in a chemical industry. Magister Commercii in Industrial Psychology dissertation. School of Behavioural Sciences, North-West University, Vanderbijlpark, Vaal Triangle.

Nunnally, J. (1978). Psychometric methods. New York: McGraw-Hill.
Nunnally, J.C., \& Bernstein, I.H. (1994). Psychological theory. New York, NY: McGrawHill, pp. 131-147.

Oyelana, A.A., \& Adu, E.O. (2015). Small and medium enterprises (SMEs) as a means of creating employment and poverty reduction in Fort Beaufort, Eastern Cape Province of South Africa. Journal of Social Sciences, 45(1), 8-15. https://doi.org/1 Province of South Africa. Journal of
$0.1080 / 09718923.2015 .11893481$

Panaccio, A., \& Vandenberghe, C. (2009). Perceived organizational support, organizationa commitment and wellbeing: A longitudinal study. Journal of Vocational Behaviour, 75(2), 224-236. https://doi.org/10.5465/ambpp.2009.44228413

Parasuraman, S., Purohit, Y.S., Godshalk, V.M., \& Beutell, N.J. (1996). Work and family variables, entrepreneurial career success and psychological well-being. Journal of Vocational Behavior, 48(3), 275-300. https://doi.org/10.1006/jvbe.1996.0025

Peng, H.J., Long, Y., \& Liang, H.J. (2012). The Tenth National Chinese Psychiatric Academic Conference, Nanjing City, China: Jiangsu Medical Association; Mental health status of the SMEs employees in the Pearl River Delta.

Rahim, N.B., \& Siti-Rohaida, M.Z. (2015). Protean career orientation and career goa development: Do they predict engineer's psychological well-being? ProcediaSocial and Behavioral Sciences, 172, 270-277. https://doi.org/10.1016/j.sbspro. 2015.01.364

Ratanasiripong, P., Kaewboonchoo, O., Bell, E., Haigh, C., Susilowati, I., Isahak, M., ... Low, W.Y. (2016). Depression, anxiety and stress among small and medium enterprise workers in Indonesia, Malaysia, Thailand, and Vietnam. Internationa Journal of Occupational Health and Public Health Nursing, 3(2), 13-29.

Reynolds, A., Fourie, H., \& Erasmus, L. (2019). A generic balanced scorecard for small and medium manufacturing enterprises in South Africa. The Southern African Journal of Entrepreneurship and Small Business Management, 11(1), 1-15. https://doi.org/10.4102/sajesbm.v11i1.193

Robbins, S.P., Chatterjee, P., \& Canda, E.R. (1998). Contemporary human behaviour theory: A critical Perspective for social Work. Boston, MA: Allyn and Bacon.

Roberts-Lombard, M., Mpinganjira, M., \& Svensson, G. (2017). Antecedents and outcomes of satisfaction in buyer-supplier relationships in South Africa: A replication study. South African Journal of Economic and Management Sciences, 20(1), 1-14. https://doi.org/10.4102/sajems.v20i1.1497

Robertson, I.T., \& Cooper, C.L. (2010). Full engagement: The integration of employee engagement and psychological well-being. Leadership \& Organization Development Journal, 31(4), 324-336. https://doi.org/10.1108/01437731011043348

Robertson, P.J. (2013). The impact of career guidance on well-being outcomes. Unpublished PhD thesis. Edinburgh Napier University.

Roemer, A., \& Harris, C. (2018). Perceived organisational support and well-being: The role of psychological capital as a mediator. SA Journal of Industrial Psychology, 44(1), 1-11. https://doi.org/10.4102/sajip.v44i0.1539

Ryan, R.M., \& Deci, E.L. (2001). To be happy or to be self-fulfilled: A review of research on hedonic and eudaimonic well-being. Annual Review of Psychology, 52, 141-166. https://doi.org/10.1146/annurev.psych.52.1.141

Ryff, C.D. (1989). Happiness is everything, or is it? Explorations on the meaning of psychological well-being. Journal of Personality and Social Psychology, 57(6), 1069-1081. https://doi.org/10.1037//0022-3514.57.6.1069

Ryff, C.D., \& Singer, B. (1998). The contours of positive human health. Psychological Inquiry, 9, 1-28. https://doi.org/10.1207/s15327965pli0901_1

Ryff's Scale Information Document. (2016). Obtained through personal contact with Carol Ryff. Unpublished internal information document. Madison, WI: UWMadison Institute on Aging (IOA).

Saks, A.M. (2006). Antecedents and consequences of employee engagement Journal of Managerial Psychology, 21(7), 600-619. https://doi.org/10.1108/ 02683940610690169

Schreiber, J.B., Nora, A., Stage, F.K., Barlow, E.A., \& King, J. (2006). Reporting structura equation modeling and confirmatory factor analysis results: A review. The Journal of Educational Research, 99(6), 323-338.

Schulz, R., \& Heckhausen, J. (1996). A life span model of successful aging. The American Psychologist, 51, 702-714. https://doi.org/10.1037//0003-066X.51.7.702

Shane, J., \& Heckhausen, J. (2019). 'Motivational theory of lifespan development'. In B.B. Baltes, C.W. Rudolph \& H. Zacher (Eds.), In work across the lifespan, (pp. 111134). London: Academic Press.

Shantz, A., Alfes, K., \& Latham, G.P. (2016). The buffering effect of perceived organizational support on the relationship between work engagement and behavioral outcomes. Human Resource Mmanagement, 55(1), 25-38. https://doi. org $/ 10.1002 / \mathrm{hrm} .21653$

Sierra, J.J., \& McQuitty, S. (2005). Service providers and customers: Social exchange theory and service loyalty. Journal of Services Marketing, 19(6), 392-400. https:// doi.org/10.1108/08876040510620166

Sitharam, S., \& Hoque, M. (2016). Factors affecting the performance of small and medium enterprises in KwaZulu-Natal, South Africa. Problems and perspectives in Management, 14(2), 277-288. https://doi.org/10.21511/ppm.14(2-2).2016.03

Struwig, F.M.W., \& Lillah, R. (2017). South African small and medium-sized enterprise owners' intention to implement an environmental management system. The Southern African Journal of Entrepreneurship and Small Business Management, 9(1), 1-8. https://doi.org/10.4102/sajesbm.v9i1.104

Su, L., \& Swanson, S.R. (2019). Perceived corporate social responsibility's impact on the well-being and supportive green behaviors of hotel employees: The mediating role of the employee-corporate relationship. Tourism Management, 72, 437-450. https://doi.org/10.1016/j.tourman.2019.01.009

Sugalski, T., \& Greenhaus, J.H. (1986). Career exploration and goal setting among managerial employees. Journal of Vocational Behaviour, 29(1), 102-114. https:// doi.org/10.1016/0001-8791(86)90033-3 
Thomas, K.W., \& Velthouse, B.A. (1990). Cognitive elements of empowerment: An 'interpretive' model of intrinsic task motivation. Academy of Management Review, 15(4), 666-681. https://doi.org/10.5465/amr.1990.4310926

Tremblay, M., Gaudet, M.C., \& Vandenberghe, C. (2019). The role of group-level perceived organizational support and collective affective commitment in the
relationship between leaders' directive and supportive behaviors and group-level helping behaviors. Personnel Review, 48(2), 417-437.

Uy, M.A., Foo, M., \& Song, Z. (2013). Joint effects of prior start-up experience and coping strategies on entrepreneurs' psychological well-being. Journal of Business Venturing, 28(5), 583-597. https://doi.org/10.1108/PR-06-2017-0172

Van der Walt, F. (2018). Workplace spirituality, work engagement and thriving at work. SA Journal of Industrial Psychology, 44(1), 1-10. https://doi.org/10.4102/sajip. v44i0.1457

Vardaman, J.M., Amism J.M., Dyson, B.P., Wright, P.M., \& Randolph R. (2012) Interpreting change as controllable: The role of network centrality and selfefficacy. Human Relations, 65(7), 835-859.

Vecchio, R.P., Justin, J.E. \& Pearce, C.L. (2010). Empowering leadership: An examination of mediating mechanisms within a hierarchical structure. The Leadership Quarterly, 21(3), 530-542. https://doi.org/10.1016/j.leaqua.2010.03.014

Ward, C., \& Berno, T. (2011). Beyond social exchange theory: Attitudes toward tourists. Annals of Tourism Research, 38(4), 1556-1569. https://doi.org/10.1016/j. annals.2011.02.005

West, S.G., Taylor, A.B., \& Wu, W. (2012). Model fit and model selection in structura equation modelling. In R.H. Hoyle (ed.), Handbook of structural equation modeling (pp. 209-231). New York: Guilford Press.

Winefield, H.R., Gill, T.F., Taylor, A.W., \& Pilkington, R.M. (2012). Psychological wellbeing and psychological distress: Is it necessary to measure both? Psychology of Well-Being, 2(3), 1-14. https://doi.org/10.1186/2211-1522-2-3
Witt, L.A., \& Carlson, D.S. (2006). The work-family interface and job performance: Moderating effects of conscientiousness and perceived organizational support. Journal of Occupational Health Psychology, 11(4), 343-357. https://doi.org/ 10.1037/1076-8998.11.4.343

Wolmarans, H.P., \& Meintjes, Q. (2015). Financial management practices in successful Small and Medium Enterprises (SMEs). The Southern African Journal of Entrepreneurship and Small Business Management, 7(1), 88-116. https://doi. org/10.4102/sajesbm.v7i1.8

Worley, J.A., Fuqua, D.R., \& Hellman, C.M. (2009). The survey of perceived organizational support: Which measure should we use? SA Journal of Industria organizational support: Which measure should we use? SA Journal of
Psychology, 35(1), 112-116. https://doi.org/10.4102/sajip.v35i1.754

Wright, T.A., \& Cropanzano, R. (2000). Psychological well-being and job satisfaction as predictors of job performance. Journal of Occupational Health Psychology, 5(1), 84-94. https://doi.org/10.1037//1076-8998.5.1.84

Yun, C.J., Lin, C.C., Tung, Y.C., \& Ko, Y.T. (2007). Associations of organizational justice and ingratiation with organizational citizenship behaviour: The beneficiary perspective. Social Behaviour and Personality: an International Journal, 36(3), 289-302.

Zeng, Z., Guo, Y., Lu, L., Han, L., Chen, W., \& Ling, L. (2014). Mental health status and work environment among workers in small-and medium-sized enterprises in Guangdong, China-a cross-sectional survey. BMC Public Health, 14(1), 1162. https://doi.org/10.1186/1471-2458-14-1162

Zikic, J., \& Klehe, U.C. (2006). Job loss as a blessing in disguise: The role of career exploration and career planning in predicting reemployment quality. Journal of Vocational Behaviour, 69, 391-409. https://doi.org/10.1016/j.jvb.2006.05.007

Žižek, S.Š., Treven, S., \& Čančer, V. (2015). Employees in Slovenia and their psychological well-being based on Ryff's model of psychological well-being. Social Indicators Research, 121(2), 483-502. https://doi.org/10.1007/s11205-014-0645-3 